\title{
INFLUENCE OF SMOKING AND BODY WEIGHT ON ADIPOKINES IN Middle Aged Women
}

\author{
S. Bergmann ${ }^{1}$, R. Siekmeier ${ }^{2}$ \\ ${ }^{1}$ Technische Universität Dresden, Universitätsklinikum Carl Gustav Carus, Institut für Klinische Chemie und Laboratoriumsmedizin, \\ Dresden, Germany; ${ }^{2}$ Federal Institute for Drugs and Medical Devices (BfArM), Bonn, Germany
}

\begin{abstract}
Objective: Quitting smoking was associated with an undesirable weight gain. Both, cigarette smoking and obesity were accompanied by subclinical systemic inflammation. This may cause unfavourable changes in (plasma) adipokine concentration. The aim of the present study was to establish the influence of moderate cigarette smoking on the concentration of the adipokines leptin and adiponectin and the pro-inflammatory factors CRP, SAA, IL-6 and TNF- $\alpha$ in nonobese $(n=138)$ and obese $(n=175)$ perimenopausal women of the DRECAN-2005 survey.

Results: Among non-obese women, adiponectin was significantly lower in smokers than in non-smokers (16.88 \pm 6.85 vs. $20.63 \pm 10.04 \mu \mathrm{g} / \mathrm{ml} ; \mathrm{P}<0.05)$. Leptin tended to lower values, too. Among obese women, none significant differences in adiponectin or leptin concentration were observed between smokers and non-smokers. In obese smokers and obese non-smokers, the adiponectin concentrations were significantly lower and the leptin concentrations were significantly higher than in non-obese non-smokers. Non-obese smokers showed significantly higher leukocyte count $(6.50 \pm 1.83$ vs. $5.51 \pm 1.31 \mathrm{GPT} / 1 ; \mathrm{P}<0.001)$ and serum amyloid A concentration $(7.81 \pm 1.25$ vs. $4.22 \pm$ $1.43 \mathrm{mg} / \mathrm{l} ; \mathrm{P}<0.05)$ than non-obese non-smokers. There were only tendencies to higher concentration of CRP, IL- 6 , and TNF- $\alpha$. In obese women, moderate cigarette smoking was not associated with higher leukocyte count or concentration of SAA. Among non-smokers, overweight was associated higher concentration of leptin $(22.16 \pm 12.16$ vs. $11.49 \pm 6.37$ $\mathrm{ng} / \mathrm{ml} ; \mathrm{P}<0.001)$ and with significantly lower concentration of adiponectin $(16.29 \pm 8.01$ vs. $20.77 \pm 9.99$ $\mu \mathrm{g} / \mathrm{ml} ; \mathrm{P}<0.001)$. Among smokers, overweight was associated with higher leptin concentration only (obese: $18.62 \pm 13.46$ vs. non-obese: $8.84 \pm 4.92 \mathrm{ng} / \mathrm{ml}$; $\mathrm{P}<0.01)$.

Conclusions: In non-obese middle aged women, even moderate cigarette smoking adversely influences the serum concentration of adiponectin and SAA. Overweight hides possible effects of smoking on cytokines and adipokines.
\end{abstract}

Key words: smoking, women, adipokines, inflammation

\section{INTRODUCTION}

The Nurses' Health study demonstrated that among women adherence to lifestyle guidelines involving diet, exercise, and abstinence from smoking was associated with a low risk of coronary heart disease. Among middle aged women, even a moderate cigarette consumption of 1-14 cigarettes per day was shown to be one of the most important cardiovascular risk factors [1]. Smoking is thought to be an important determinant of body weight. Cigarette smoking was associated with lower body weight, and quitting smoking typically produces weight gain. Especially perimenopausal women do not quit or start smoking to keep their body weight. Both cigarette smoking and obesity are accompanied by a low grade subclinical chronic inflammation. In obesity, this is due probably to the secretion of pro-inflammatory cytokines (TNF- $\alpha$ and IL- 6 ) by adipocytes [2]. Cigarette smoking shows an inflammatory impact on lung tissue. It promotes leukocytosis $[3,4]$. Current smoking has an adverse effect on serum concentration of CRP [5] and it has been identified as a significant determinant of leptin and adiponectin serum concentration $[6,7]$. The aim of the present study was to establish how moderate cigarette smoking influences the serum concentration of pro-inflammatory factors (SAA, IL- 6 , and TNF- $\alpha$ ) and adipokines (adiponectin and leptin) in non-obese and obese women at perimenopausal age.

\section{Material AND Methods}

Three hundred fourteen female participants of the 6th survey of the DRECAN-study (DRECAN-2005), aged 40-68, were included into the present study $[8,9]$. The basic programme of the DRECAN studies consisted of the measurement of selected anthropometric data, personal and family history taking, and an interview-supported questionnaire according to cardiovascular risk factors and lifestyle. Fasting blood was taken in the morning between 8:00 and 10:00. Basic haematological (GenS, Beckman-Coulter, Sinsheim, Germany) and clinical chemistry analyses (MODULAR, ROCHE, Mannheim, Germany; Dx80, Beckman-Coulter, Sinsheim, Germany) were performed within 3 hours using routine methods (www.tu-dresden.de/medikl). 
Numerous aliquots of serum and fluoride-EDTAplasma were kept at $-20^{\circ} \mathrm{C}$ for several months and analyzed serially for serum-amyloid A (SAA), hsCRP (ProSpec, Siemens, Eschborn, Germany), and TNF- $\alpha$, IL-6 (Immulite, Siemens, Eschborn, Germany). Serum leptin and adiponectin concentration were measured using the LINCO Ltd. Research (St. Charles, USA) RIA methods. Among non-obese women of the DRECAN population (aged 19-70), the adiponectin concentration varied between the interquartile of 13.83-26.33 $\mu \mathrm{g} / \mathrm{ml}$ (median: $19.04 \mu \mathrm{g} / \mathrm{ml}$ ) and the leptin concentration between the interquartile of 7.3-13.45 ng/ml, (median: $10.7 \mathrm{ng} / \mathrm{ml}$ ). Data are given as means $\pm S D$. Statistical analyses were performed with SPPS 12.0-16.0 software package.

\section{RESULTS}

\section{AlL WomeN}

$56.6 \%(\mathrm{n}=175)$ of the participants were obese (BMI $>25.00 \mathrm{~kg} / \mathrm{m}^{2}$; Table1). The adiponectin concentration was significantly lower in the obese $(16.92 \pm 8.04$ $\mu \mathrm{g} / \mathrm{ml}$ vs. $21.22 \pm 9.63 \mu \mathrm{g} / \mathrm{ml} ; \mathrm{P}<0.001)$ than nonobese women. The leptin concentration (23.05 \pm $12.36 \mathrm{ng} / \mathrm{ml}$ vs. $11.19 \pm 5.90 \mathrm{ng} / \mathrm{ml} ; \mathrm{P}<0.001)$ and the leukocyte count $(6.15 \pm 1.58$ vs. $5.76 \pm 1.37 \mathrm{GPT} / \mathrm{l}$ $\mathrm{P}<0.05)$ were significantly higher in obese women.

$17.9 \%$ of participants $(n=56)$ were moderate smokers ( $\leq 10$ cigarettes per day): $18.3 \%$ in the non-obese and $17.7 \%$ in obese women. All non-smokers were lifelong non-smokers. No significant differences in body mass index (BMI) or waist circumference were found between smokers and non-smokers: BMI in smokers $24.76 \pm 4.05 \mathrm{~kg} / \mathrm{m}^{2}$; non-smokers $25.64 \pm$ $4.07 \mathrm{~kg} / \mathrm{m}^{2}$; waist $86 \pm 12 \mathrm{~cm}$ in both (Table 1). There were no significant differences in the adiponectin (smokers: $17.68 \pm 6.80 \mu \mathrm{g} / \mathrm{ml}$; non-smokers: $18.94 \pm$ $9.19 \mu \mathrm{g} / \mathrm{ml}$ ) or leptin concentration (smokers: $16.31 \pm$ $11.84 \mathrm{ng} / \mathrm{ml}$; non-smokers: $17.84 \pm 11.24 \mathrm{ng} / \mathrm{ml}$ ) between smokers and non-smokers.

\section{NON-SMOKERS}

Among non-smokers, the adiponectin concentration was significantly lower and the leptin concentration significantly higher in the obese women (Table 1). Adiponectin, leptin, and their ratio were closely correlated with BMI, leukocyte count, and CRP (Table 2). Leptin concentration and the $\mathrm{A} / \mathrm{L}$ ratio but not adiponectin are correlated with SAA. After adjustment for BMI only the positive correlation between leptin and SAA persisted (Table 2). In obese non-smokers the concentration of CRP (median $2.10 \mathrm{mg} / 1$ [1.403.65] vs. median $1.10 \mathrm{mg} / 1$ [1.00-1.80]; Mann-Whitney $\mathrm{P}<0.001$ ) and SAA (median $5.15 \mathrm{mg} / 1$ [3.40-9.55] vs. median $3.75 \mathrm{mg} / 1$ [3.10-4.90]; Mann-Whitney $\mathrm{P}<0.01$ ) are significantly higher than in the reference group. The concentration of TNF- $\alpha$ (non-obese: median 7.5 $\mathrm{ng} / \mathrm{ml}$ [5.9-11.8]); obese: median $8.3 \mathrm{ng} / \mathrm{ml}$ [6.1-10.8] and IL-6 (non-obese: median $2.0 \mathrm{ng} / \mathrm{ml}$ [1.9-2.3]; obese: median $2.0 \mathrm{ng} / \mathrm{ml}$ [1.9-2.4]) are not influenced by the body weight significantly.

Table 1. Characteristics of the population.

\begin{tabular}{|c|c|c|c|c|}
\hline & $\begin{array}{l}\text { Non-obese } \\
\text { smokers }\end{array}$ & $\begin{array}{l}\text { Non-obese } \\
\text { non-smokers \& }\end{array}$ & $\begin{array}{l}\text { Obese } \\
\text { smokers }\end{array}$ & $\begin{array}{l}\text { Obese } \\
\text { non-smokers }\end{array}$ \\
\hline $\mathrm{n}$ & 25 & 113 & 31 & 144 \\
\hline Age (years) & $43.7 \pm 12.5$ & $53.4 \pm 13.0 \$ \mathbb{S}$ & $52.9 \pm 11.6 \$ \$$ & $58.5 \pm 8.7 \S$ \\
\hline $\mathrm{BMI}\left(\mathrm{kg} / \mathrm{m}^{2}\right)$ & $22.23 \pm 1.58$ & $22.49 \pm 1.79$ & $28.39 \pm 3.35^{* * *}$ & $28.60 \pm 3.17 * * *$ \\
\hline Waist circumference $(\mathrm{cm})$ & $78.6 \pm 8.0$ & $78.4 \pm 7.1$ & $95.3 \pm 11.7 * * *$ & $93.5 \pm 9.5^{* * *}$ \\
\hline BPsys (mmHg) & $113 \pm 15$ & $127 \pm 19 \$ \$ S$ & $134 \pm 16 \$ \int$ & $139 \pm 18^{* * \text { SSS }}$ \\
\hline BPdias (mmHg) & $72 \pm 11$ & $79 \pm 10 \$ \mathbb{S}$ & $82 \pm 8 \int \varsigma$ & $85 \pm 9 * * \$ \int S$ \\
\hline Leukocytes (GPt/l) & $6.50 \pm 1.83^{* * *}$ & $5.51 \pm 1.32$ & $6.21 \pm 1.67$ & $6.05 \pm 1.47 * *$ \\
\hline $\mathrm{CRP \#}(\mathrm{mg} / \mathrm{l})$ & 2.82 & 2.14 & 2.83 & $2.88^{*}$ \\
\hline $\mathrm{SAA}(\mathrm{mg} / \mathrm{l})$ & $7.81 \pm 1.26^{*}$ & $4.22 \pm 1.48$ & $5.35 \pm 3.24$ & $6.74 \pm 4.04 *$ \\
\hline TNF $\alpha \#$ (ng/ml) & 10.54 & 9.80 & 8.91 & 17.81 \\
\hline IL-6\# (ng/ml) & 2.82 & 2.60 & 2.27 & 2.40 \\
\hline TG (mmol/l) & $1.20 \pm 0.75$ & $1.14 \pm 1.60$ & $1.58 \pm 0.74^{* *}$ & $1.29 \pm 0.64 *$ \\
\hline $\mathrm{TC}(\mathrm{mmol} / \mathrm{l})$ & $5.40 \pm 0.93^{*}$ & $5.78 \pm 1.00$ & $5.97 \pm 0.64^{* *}$ & $5.90 \pm 0.89$ \\
\hline LDL-C (mmol/l) & $3.19 \pm 0.75^{*}$ & $3.56 \pm 0.94$ & $3.96 \pm 0.67 * * *$ & $3.78 \pm 0.83 \Omega$ \\
\hline HDL-C (mmol/l) & $2.07 \pm 0.46$ & $2.12 \pm 0.50$ & $1.71 \pm 0.44 * * \S$ & $1.91 \pm 0.45 \Omega \Omega s$ \\
\hline $\mathrm{TSH}(\mathrm{U} / \mathrm{l})$ & $2.14 \pm 2.40$ & $1.55 \pm 1.00$ & $1.63 \pm 0.99$ & $1.68 \pm 1.11$ \\
\hline HOMA & $1.62 \pm 0.58$ & $2.17 \pm 4.14$ & $3.15 \pm 2.18 * * \Omega \Omega$ & $2.98 \pm 2.10^{* *}$ \\
\hline Adiponectin $(\mu \mathrm{g} / \mathrm{ml})$ & $16.88 \pm 8.85^{*}$ & $20.76 \pm 9.89$ & $14.14 \pm 7.68^{* *}$ & $16.29 \pm 8.01 * * *$ \\
\hline $\begin{array}{l}\text { Leptin }(\mathrm{ng} / \mathrm{ml}) \\
\text { A/L ratio }\end{array}$ & $\begin{array}{l}8.84 \pm 4.92 \\
2.61 \pm 1.83\end{array}$ & $\begin{array}{l}11.49 \pm 6.37 \\
2.45 \pm 1.78\end{array}$ & $\begin{array}{l}18.62 \pm 13.46 * * \$ S \\
1.20 \pm 0.86 * * \$ S\end{array}$ & $\begin{array}{l}22.16 \pm 12.16 * * \$ \delta S \\
1.14 \pm 1.42^{* * * \delta \Omega}\end{array}$ \\
\hline
\end{tabular}

$* \mathrm{P}<0.05$. ${ }^{*} * \mathrm{P}<0.01$. ${ }^{*} * * \mathrm{P}<0.001$ vs. non-obese non-smoker; $\$ \mathrm{P}<0.05$. $\$ \$ \mathrm{P}<0.01$. $\$ \$ \$ \mathrm{P}<0.001$ vs. non-obese smoker; \#median and interquartile; \&reference group (see text for details). 
Table 2. Partial correlation between adipokines and markers of low grade systemic inflammation in dependency on BMI.

\begin{tabular}{|c|c|c|c|c|c|c|}
\hline & $\begin{array}{l}\text { Adiponectin } \\
\text { bivariate }\end{array}$ & $\begin{array}{l}\text { BMI } \\
\text { adjusted }\end{array}$ & $\begin{array}{l}\text { Leptin } \\
\text { bivariate }\end{array}$ & $\begin{array}{l}\text { BMI } \\
\text { adjusted }\end{array}$ & $\begin{array}{l}\text { A / L ratio } \\
\text { bivariate }\end{array}$ & $\begin{array}{l}\text { BMI } \\
\text { adjusted }\end{array}$ \\
\hline \multicolumn{7}{|c|}{ Smokers } \\
\hline BMI & -0.021 & & $0.766^{* * *}$ & & $-0.560 * * *$ & \\
\hline Leukocytes & -0.198 & -0.197 & $0.289^{+}$ & $0.275^{+}$ & -0.075 & 0.009 \\
\hline CRP & 0.002 & & -0.086 & & 0.091 & \\
\hline $\mathrm{SAA}$ & 0.060 & 0.060 & -0.062 & $-0,083$ & 0.021 & 0.018 \\
\hline TNF- $\alpha$ & -0.41 & -0.047 & -0.197 & -0.048 & 0.197 & 0.093 \\
\hline IL-6 & 0.035 & 0.034 & -0.079 & -0.054 & 0.015 & -0.021 \\
\hline \multicolumn{7}{|c|}{ Non-smokers } \\
\hline $\mathrm{BMI}$ & $-0.255^{* * *}$ & & $0.657 * * *$ & & $-0.379 * * *$ & \\
\hline Leukocytes & $-0.127^{+}$ & -0.82 & $0.166^{*}$ & 0.054 & $-0.203^{* *}$ & -0.144 \\
\hline CRP & $-0.13^{*}$ & -0.61 & $0.245^{* * *}$ & 0.076 & $-0.185^{* *}$ & -0.075 \\
\hline SAA & -0.182 & -0.07 & $0.627^{* * * *}$ & $0.469 * * *$ & $-0.347^{* *}$ & $-0.202^{+}$ \\
\hline $\mathrm{TNF}-\alpha$ & -0.02 & -0.006 & -0.07 & $-0.142^{+}$ & 0.14 & 0.038 \\
\hline IL-6 & 0.129 & $0.142^{+}$ & 0.013 & -0.008 & 0.123 & $0.145^{+}$ \\
\hline
\end{tabular}

${ }^{+} \mathrm{P}<0.1, * \mathrm{P}<0.05, * * \mathrm{P}<0.01, * * * \mathrm{P}<0.001$

\section{SMOKERS}

Non-obese smokers are significantly younger than other three subgroups. The adiponectin concentration is comparable between obese and non-obese smokers (Table 1). In bivariate analysis, the leptin concentration and the $\mathrm{A} / \mathrm{L}$ ratio were significantly correlated with BMI (Table 2). The leptin concentration was significantly higher and the adiponectin/leptin ratio was lower in the obese smokers than in non-obese smokers (Table 1). The concentration of CRP was comparable in obese (median $1.90 \mathrm{mg} / 1$ [1.35-3.52]) and nonobese smokers (median $4.80 \mathrm{mg} / 1$ [2.95-8.10]), whereas the concentration of SAA was significantly higher in obese smokers (median $1.30 \mathrm{mg} / 1$ [1.00-2.20]) than in non-obese (median $1.30 \mathrm{mg} / \mathrm{l}$ [1.00-3.52]; MannWhitney $\mathrm{P}<0.05)$. The concentration of TNF- $\alpha$ (obese: median $7.8 \mathrm{ng} / \mathrm{ml}$ [4.3-9.9] vs. non-obese: median $7.9 \mathrm{ng} / \mathrm{ml}$ [6.6-12.3]) and IL-6 (obese: median 2.2 $\mathrm{ng} / \mathrm{ml}$ [2.0-2.8] vs. non-obese: median $1.9 \mathrm{ng} / \mathrm{ml}$ [1.93.1]) were comparable in both obese and non-obese smokers.

\section{Discussion}

A moderate effect of cigarette smoking on body weight is associated with an increase of the visceral obesity [10]. Obesity promotes hypoadiponectinemia. Smoking decreases body weight. Quitters are at higher risk of weight gain. Adipose tissue has been considered an important endocrine organ that secretes biologically active substances, including adipocytokines involved in inflammation (TNF- $\alpha$, IL- 6 , IL-10, and IL-1B), components of the acute phase response (SAA and PAI-I), and hormonal active adipokines (leptin, adiponectin, and resistin) $[11,12]$. It is evident that adiponectin protects and leptin accelerates the development of atherosclerotic diseases. Despite the wellknown inverse association between smoking and body weight, there have been conflicting reports on the association between smoking and adipokines, such as leptin and adiponectin.

Our hypotheses in the present study were as follows: (i) even moderate cigarette smoking decreases the serum concentration of adiponectin and has little effect on the concentration of leptin; these changes would be accompanied by signs of a low grade subclinical chronic inflammation and would be weight-dependent. We found comparable concentrations of both adipokines in smokers and non-smokers in the unselected study population. Both smoking and body weight decreased the adiponectin concentration, whereas leptin was influenced by the body weight predominantly.

\section{ADIPONECTIN}

Adiponectin is an adipocytokine with insulin-sensitizing, anti-inflammatory, and anti-atherogenic properties. In epidemiological studies, a paradoxical relationship between adiponectin and BMI was described [13]. Weight loss resulted in decreasing adiponectin serum concentration $[14,15]$. Adiponectin is a marker of adipocyte differentiation. Secretion of adiponectin is closely associated with the expression of the pro-inflammatory cytokines IL- 6 and TNF- $\alpha$ in adipocytes [16]. Adiponectin is an important player in the regulation of the inflammatory response [17]. Cigarette smoke extract dose-dependently inhibits the differentiation of pre-adipocytes into adipocytes, which is accompanied by a blunted expression of adipocyte marker adiponectin [19]. In men, current smoking is reflected by reduced plasma adiponectin levels $[7,20]$. In the present study, we found a significantly lower adiponectin concentration in smokers, but only in the non-obese ones. In contrast to non-smokers, there was no correlation between adiponectin concentration and BMI, supporting the observation that the weight re- 
ducing effect obtained by smoking is accompanied by increasing amount of visceral fat [10]. In the obese group, the adiponectin decreasing effect of the overweight seemed to tower above the additional effect of cigarette smoking. Recently, Sull et al [20] discussed that lower serum adiponectin concentrations in smokers may not be dependent on the insulin resistance status or obesity. Smoking cessation restored the adiponectin and leptin levels [18]. Quitters' post-cessation adiponectin levels are significantly increased. Serum adiponectin levels appeared to increase considerably within two months after smoking cessation. This finding may provide further insight into the mechanisms related to the benefits of quitting smoking [7].

\section{LEPTIN}

Leptin, a product of the ob gene, is an adipose tissuederived hormone that appears to regulate both satiety and thermogenesis. It is known to play a role in food intake regulation. Circulating plasma leptin is primarily a function of adiposity [23]. It is released from adipocyte in direct proportion to fat mass [24]. In men, fat mass is the best predictor of serum leptin concentration. In women, percentage body fat is the best predictor of leptin [23]. In healthy non-obese populations, fasting serum leptin concentration is significantly higher in women than in men $[18,21,23$, 24]. In 20-70 years old women without signs of an acute inflammatory process (DRECAN-2005 population), leptin concentration has positively correlated with BMI, leukocyte count, and CRP concentration even after adjustment for age or waist circumference [8]. The concentration of leptin is significantly lower in obese middle-aged women as compared with nonobese women. Moderate cigarette smoking is associated with a tendency to lower concentration of fasting serum leptin in both obese and non-obese women. In the US population, leptin concentration is significantly associated with sex, age, BMI, fasting plasma glucose and insulin, serum triglycerides, but not with smoking, race-ethnicity, energy, and alcohol intake [21]. There is no difference in mean leptin levels as a function of smoking status after controlling for BMI and age [25]. In the present study population, moderate smokers with a BMI below $25 \mathrm{~kg} / \mathrm{m}^{2}$ tended to have lower leptin concentration as compared with non-obese nonsmokers. The same tendency was observed in the obese subgroup. This may reflect an improvement in leptin sensitivity. On the other hand, one may speculate that this decline becomes significantly with increasing cigarette consumption. Al Mutairi et al [6] described a dose-dependent effect of smoking on leptin, BMI, and the sOb-receptor. Compared with control subjects, smoking cigarettes has been associated with significantly lower serum leptin, sOb-R, and free leptin levels. Perkins found no difference in leptin concentration due to smoking status, but smoking cessation for three weeks increased leptin levels in women only [25]. Leptin expression is increased in bronchial epithelial cells and alveolar macrophages of ex-smokers with or without severe COPD compared with never smokers. A functional leptin signaling path- way has been detected in lung epithelial cells [26]. Smoking may modify leptin receptors and modulate leptin synthesis. The weight-lowering effect of smoking probably is not related to leptin-induced anorectic signals [6].

\section{INFLAMMATION}

Systemic inflammation is important in the pathogenesis of cardiovascular disease. Despite the well-known inverse association between smoking and body weight, molecular mechanisms underlying this phenomenon have not been elucidated completely. Data published by Shimada et al [19] suggested that cigarette smoke has the potential to inhibit adipocyte differentiation via dual, independent mechanisms. Increased tissue concentration of the pro-inflammatory cytokines impaired the normal differentiation of pre-adipocytes into adipocytes. This may result in decreasing serum concentration of adiponectin [16]. In the present study, decreasing concentration of adiponectin was not accompanied by a measurable elevation in serum levels of TNF- $\alpha$, IL- 6 , or CRP. A pro-inflammatory effect of cigarette smoking was demonstrable in increased leukocyte count in all smokers and higher SAA concentration in non-obese smokers.

\section{CRP}

Circulating C-reactive protein (CRP), as an inflammation marker, is associated with the incidence of cardiovascular events. Increasing plasma concentration of CRP reflect an inflammatory process caused by the release of proinflammatory cytokines (IL-6 or TNF- $\alpha$ ). CRP stimulates the classical way of the complement cascade and may induce the induction of cytokines itself. Adiponectin decreases the synthesis and secretion of CRP from endothelial cells via modulation of the AMP-kinase signaling pathway [27] and negatively regulates CRP expression in adipocytes [17]. CRP seems to be a useful biomarker for an obesity-caused subclinical inflammation [2]. In men, serum concentration of CRP correlates with WHR [28]. Weight loss is associated with a decline in serum concentration of CRP [29]. Beside the liver, macrophages, smooth muscle cells and adipocytes produce CRP. In adipose tissue, an inverse relationship between CRP and adiponectin mRNA has been described [17]. In Japanese men, both leptin (negatively) and adiponectin (positively) are independently associated with CRP concentration [30]. Leptin is more strongly related to CRP levels than adiponectin, especially among obese men [30]. Among women of the DRECAN-05 population, leptin concentration highly correlated with CRP and BMI [8]. In the present study, a correlation with CRP could be confirmed in non-smokers only. There exists a strong inverse correlation between CRP and adiponectin mRNA [31]. In healthy obese women or in non-diabetic women, adiponectin serum concentration correlates with CRP $[32,33]$. In a subgroup of nonsmokers of the present study, the correlation of adiponectin with CRP was weak and it was not demonstrable in smokers. Maybe, this was due to different menopausal status and use of hormone replace- 
ments. Hormone replacement therapy seems to increase the serum concentration of CRP $[5,34]$. Postmenopausal women in the lowest quartile of visceral fat and not on HRT show a significantly lower CRP than women in the highest quartile of visceral fat independently of HRT use [35].

$$
\text { IL-6 }
$$

Diabetes and metabolic syndrome are associated with increased low grade inflammation [27]. IL-6 acts on hepatocytes inducing the acute phase reaction/reactants. Among non-smokers, the plasma level of IL-6 correlates with absolute and relative fat mass, fasting insulin, and blood pressure. These effects are dependent on gender and current smoking status [8, 36]. Among women, the correlation of IL-6 with fasting insulin could not be observed. Adiponectin is able to inhibit the activation of $\mathrm{NF}-\kappa \mathrm{B}$ in macrophages and endothelial cells. Hypoadiponectinemia increases concentrations of IL- 6 and IL- 8 in plasma $[17,37]$. In the present study, after adjustment for BMI, we found only a weak correlation of adiponectin and the $\mathrm{A} / \mathrm{L}$ ratio with IL-6 in non-smokers.

\section{TNF- $\alpha$}

Tumor necrosis factor alpha (TNF- $\alpha$ ) is produced mainly by macrophages in response to inflammation or cancer and by adipocytes [38, 39]. In adipocytes, pro-inflammatory cytokines such as TNF- $\alpha$ downregulate the expression of adiponectin and upregulate the production of leptin [40]. Adiponectin again inversely regulates the TNF- $\alpha$ expression in the adipose tissue [17]. It is still unclear whether an increased TNF- $\alpha$ production in the adipose tissue is reflected by increased serum concentration [41]. Moderate cigarette consumption in middle aged women was not reflected by increased serum concentration of TNF- $\alpha$ or significant correlation between adiponectin and TNF- $\alpha$ in smokers.

Conflicts of interest: There are no personal potential financial conflicts of interest declared by the authors, according to employment, honoraria, grants received, consultancies, patents received, or stock ownerships, in relation to this article.

\section{REFERENCES}

[1] Stampfer MJ, Hu FB, Manson JE, Rimm EB, Willett WC. Primary prevention of coronary heart disease in women through diet and lifestyle. N Engl J Med 2000; 343: 16-22.

[2] Yudkin JS, Stehouwer CD, Emeis JJ, Coppack SW. C-reactive protein in healthy subjects: associations with obesity, insulin resistance, and endothelial dysfunction: a potential role for cytokines originating from adipose tissue? Arterioscler Thromb Vasc Biol 1999; 19: 972-8.

[3] Zalokar JB, Richard JL, Claude JR. Leukocyte count, smoking, and myocardial infarction. N Engl J Med 1981; 304: 465-8.

[4] Bergmann S, Siekmeier R, Mix C, Jaross W. Even moderate cigarette smoking influences the pattern of circulating monocytes and the concentration of sICAM-1. Respir Physiol 1998; 114: 269-75.

[5] Garcia-Moll X, Zouridakis E, Cole D, Kaski JC. C-reactive protein in patients with chronic stable angina: differences in baseline serum concentration between women and men. Eur Heart J 2000; 21: 1598-606.

[6] Al Mutairi SS, Mojiminiyi OA, Shihab-Eldeen AA, Al SA, Abdella N. Effect of smoking habit on circulating adipokines in diabetic and non-diabetic subjects. Ann Nutr Metab 2008; 52: 329-34.

[7] Efstathiou SP, Skeva II, Dimas C, et al. Smoking cessation increases serum adiponectin levels in an apparently healthy Greek population. Atherosclerosis 2009.

[8] Bergmann S, Richter F, Assig K, Siekmeier R. Leptin, CRP und Leukozyten bei moderaten Raucherinnen. AtemwLungenkrkh 2007; 33: 318-23.

[9] Jaross W, Assmann G, Bergmann S, Schulte H. Comparison of risk factors for coronary heart disease in Dresden and Munster. Results of the DRECAN (Dresden Cardiovascular Risk and Nutrition) study and the PROCAM (Prospective Cardiovascular Munster) Study. Eur J Epidemiol 1994; 10: 307-15.

[10] Canoy D, Wareham N, Luben R, et al. Cigarette smoking and fat distribution in 21,828 British men and women: a population-based study. Obes Res 2005; 13: 1466-75.

[11] Matsuzawa Y, Funahashi T, Kihara S, Shimomura I. Adiponectin and metabolic syndrome. Arterioscler Thromb Vasc Biol 2004; 24: 29-33.

[12] Vettor R, Milan G, Rossato M, Federspil G. Review article: adipocytokines and insulin resistance. Aliment Pharmacol Ther 2005; 22 Suppl 2: 3-10.

[13] Arita Y, Kihara S, Ouchi N, et al. Paradoxical decrease of an adipose-specific protein, adiponectin, in obesity. Biochem Biophys Res Commun 1999; 257: 79-83.

[14] Ziccardi P, Nappo F, Giugliano G, et al. Reduction of inflammatory cytokine concentrations and improvement of endothelial functions in obese women after weight loss over one year. Circulation 2002; 105: 804-9.

[15] Yang WS, Lee WJ, Funahashi T, et al. Weight reduction increases plasma levels of an adipose-derived anti-inflammatory protein, adiponectin. J Clin Endocrinol Metab 2001; 86: 3815-9.

[16] Gustafson B, Hammarstedt A, Andersson CX, Smith U. Inflamed adipose tissue: a culprit underlying the metabolic syndrome and atherosclerosis. Arterioscler Thromb Vasc Biol 2007; 27: 2276-83.

[17] Ouchi N, Walsh K. Adiponectin as an anti-inflammatory factor. Clin Chim Acta 2007; 380: 24-30.

[18] Al-Daghri NM, Al-Attas OS, Al-Rubeaan K, Sallam R. Adipocytokine profile of type 2 diabetics in metabolic syndrome as defined by various criteria. Diabetes Metab Res Rev 2008; 24: 52-8.

[19] Shimada T, Hiramatsu N, Hayakawa K, et al. Dual suppression of adipogenesis by cigarette smoke through activation of the aryl hydrocarbon receptor and induction of endoplasmic reticulum stress. Am J Physiol Endocrinol Metab 2009; 296: E721-E730.

[20] Sull JW, Kim HJ, Yun JE, et al. Serum adiponectin is associated with smoking status in healthy Korean men. Endocr J 2009; 56: 73-8.

[21] Ganji V, Kafai MR, McCarthy E. Serum leptin concentrations are not related to dietary patterns but are related to sex, age, body mass index, serum triacylglycerol, serum insulin, and plasma glucose in the US population. Nutr Metab (Lond) 2009; 6: 3.

[22] Otsuka F, Kojima S, Maruyoshi H, et al. Smoking cessation is associated with increased plasma adiponectin levels in men. J Cardiol 2009; 53: 219-25.

[23] Hickey MS, Israel RG, Gardiner SN, et al. Gender differences in serum leptin levels in humans. Biochem $\mathrm{Mol}$ Med 1996; 59: 1-6.

[24] Considine RV, Sinha MK, Heiman ML, et al. Serum immunoreactive-leptin concentrations in normal-weight and obese humans. N Engl J Med 1996; 334: 292-5. 
[25] Perkins KA, Fonte C. Effects of smoking status and smoking cessation on leptin levels. Nicotine Tob Res 2002; 4: 459-66.

[26] Vernooy JH, Drummen NE, van Suylen RJ, et al. Enhanced pulmonary leptin expression in patients with severe COPD and asymptomatic smokers. Thorax 2009; 64: 26-32.

[27] Devaraj S, Torok N, Dasu MR, Samols D, Jialal I. Adiponectin decreases C-reactive protein synthesis and secretion from endothelial cells: evidence for an adipose tissue-vascular loop. Arterioscler Thromb Vasc Biol 2008; 28: 1368-74.

[28] Fernandez-Real JM, Vayreda M, Richart C, et al. Circulating interleukin 6 levels, blood pressure, and insulin sensitivity in apparently healthy men and women. J Clin Endocrinol Metab 2001; 86: 1154-9.

[29] Selvin E, Paynter NP, Erlinger TP. The effect of weight loss on C-reactive protein: a systematic review. Arch Intern Med 2007; 167: 31-9.

[30] Sugiura K, Tamakoshi K, Yatsuya H, et al. Contribution of adipocytokines to low-grade inflammatory state as expressed by circulating C-reactive protein in Japanese men: comparison of leptin and adiponectin. Int J Cardiol 2008; 130: 159-64.

[31] Ouchi N, Kihara S, Funahashi T, et al. Reciprocal association of C-reactive protein with adiponectin in blood stream and adipose tissue. Circulation 2003; 107: 671-4.

[32] Engeli S, Feldpausch M, Gorzelniak K, et al. Association between adiponectin and mediators of inflammation in obese women. Diabetes 2003; 52: 942-7.

[33] Matsubara M, Namioka K, Katayose S. Decreased plasma adiponectin concentrations in women with low-grade C-reactive protein elevation. Eur J Endocrinol 2003; 148 657-62.

[34] Ridker PM, Hennekens CH, Rifai N, Buring JE, Manson JE. Hormone replacement therapy and increased plasma concentration of C-reactive protein. Circulation 1999; 100: 713-6.
[35] Barinas-Mitchell E, Cushman M, Meilahn EN, Tracy RP, Kuller LH. Serum levels of C-reactive protein are associated with obesity, weight gain, and hormone replacement therapy in healthy postmenopausal women. Am J Epidemiol 2001; 153: 1094-101.

[36] Fernandez-Real JM, Vendrell J, Ricart W. Circulating adiponectin and plasma fatty acid profile. Clin Chem 2005; 51: 603-9.

[37] Kobashi C, Urakaze M, Kishida M, et al. Adiponectin inhibits endothelial synthesis of interleukin-8. Circ Res 2005; 97: 1245-52.

[38] Hauner H. Obesity and leptin. Dtsch Med Wochenschr 1998; 123: 1315-6.

[39] Hotamisligil GS, Arner P, Caro JF, Atkinson RL, Spiegelman BM. Increased adipose tissue expression of tumor necrosis factor-alpha in human obesity and insulin resistance. J Clin Invest 1995; 95: 2409-15.

[40] Popa C, Netea MG, van Riel PL, van der Meer JW, Stalenhoef AF. The role of TNF-alpha in chronic inflammatory conditions, intermediary metabolism, and cardiovascular risk. J Lipid Res 2007; 48: 751-62.

[41] Zahorska-Markiewicz B, Janowska J, Olszanecka-Glinianowicz M, Zurakowski A. Serum concentrations of TNF-alpha and soluble TNF-alpha receptors in obesity. Int J Obes Relat Metab Disord 2000; 24: 1392-5.

Address for correspondence:

Prof. Sybille Bergmann

TU Dresden UKD IKI

Fetscherstr. 74

01307 Dresden

Germany

Phone: +493514583490

Fax: $\quad+493514584332$

E-mail: Sybille.bergmann@uniklinikum-dresden.de 